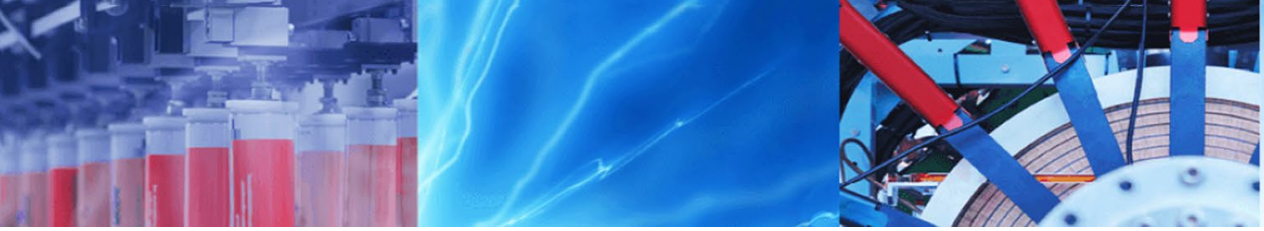

Research Article

\title{
Investigating the properties of bentonite and kaolin modified concrete as a partial substitute to cement
}

\author{
Seyedeh Marzieh Qiyami Taklymi ${ }^{1} \cdot$ Omid Rezaifar $^{1} \cdot$ Majid Gholhaki $^{1}$
}

Received: 22 December 2019 / Accepted: 19 August 2020 / Published online: 19 November 2020

(c) Springer Nature Switzerland AG 2020

\begin{abstract}
Using pozzolanic materials in concrete manufacturing is intended as an optimal solution to lower the rate of greenhouse gas emission, and diminish energy resources and cement consumption. This study investigates the effect of using Semnan bentonite and kaolin as partial replacement for cement in low-strength concretes. A total of 18 mix designs along with a control specimen are prepared and compared. The main parameter is considered to be the changes in the ratio of bentonite, kaolin, and natural materials (furnace slag and gum vine-resin) to the cement weight. For better evaluation the water to cementitious materials ratio (W/C) and the fine aggregate percentage considered constant. To study properties of hardened concrete, compressive strength and splitting tensile strength tests were performed. According to the results of compressive strength test, using bentonite, kaolin, and other substances (furnace slag and natural resin) at $2 / 7 \%$ ratio by weight of cement, for a $400 \mathrm{~kg} / \mathrm{m}^{3}$ cement content, could improve the compressive strength by nearly $6 \%$. However, at a lower cement content, the additives reduced the compressive strength and, consequently, the tensile strength. According to the results in mixtures containing bentonite, kaolin and natural materials (furnace slag and gum vine-resin) if the amount of bentonite, kaolin and natural materials is more than $2 / 7 \%$ by weight of cement, the tensile strength is reduced by $75 \%$ compared to CM. Accordingly, without cement, both compressive and tensile strength decreased drastically. It was decided that pozzolanic materials cannot be used alone, and their role must be limited to that of a partial substitute. Specimens with $400 \mathrm{~kg} / \mathrm{m}^{3}$ cement offered an acceptable compressive strength for low-rise structures.
\end{abstract}

Keywords Pozzolanic materials · Bentonite $\cdot$ Kaolin $\cdot$ Compressive strength $\cdot$ Tensile strength

\section{Introduction}

Sustainable development is a development intended to enhance the quality of life and meet the basic needs according to the abilities of the next generations. Sustainable development is one of the most comprehensive concepts throughout the ages. It aims to meet basic needs, improve living standards, and better protect and manage the ecosystems $[1,2]$. Due to increasing concerns on environmental pollution, fossil energy shortage, and sustainable development, the recycling of industrial by-products had become a popular practice worldwide [3].
The concrete industry is a large consumer of natural materials in the world [4]. The relationship between the energy consumption in the industry and the energy-saving was investigated by Lu et al. [5]. Therefore, the recycled aggregates and natural pozzolanic materials can be used to save energy and improve the sustainability of construction industry [6-8].

Green building design is possible using sustainable materials with better or similar properties relative to the conventional building materials. However, some questions arise, such as: Are the construction materials used in the sustainable cement commercially available and easily

Omid Rezaifar, orezayfar@semnan.ac.ir | ${ }^{1}$ Faculty of Civil Engineering, Semnan University, Semnan, Iran. 
accessible? Do sustainable cements comply with conventional regulations? Are they comparable to common materials and can they be compared with conventional materials [9]? How can more sustainable products be produced? Also, current methods and models presented in the development process of sustainable products have been studied at several conferences [10].

Using ordinary Portland cement has adverse effects on the environment. Among the environmental damages caused by the Portland cement are the significant emissions and thermal energy [11-13]. On the other hand, the increase in the cost of environmental taxes that occurred after the Kyoto protocol [14] also led to other non-harmful materials to be studied and replaced.

To produce one ton of cement, about one ton of carbon dioxide is produced. The production of this amount of carbon dioxide can increase the earth's temperature and the number of greenhouse gases. A significant concern is global warming, increase in earth temperature and it's destructive effect, and all the international communities are trying to resolve the factors causing this problem and crisis. One of the proposed solutions is to reduce the amount of consumed energy and natural raw materials. In this regard, one of the factors causing these problems is found to be the cement industry.

The use of ordinary Portland cement (OPC) is associated with some environmental concerns [15] because cement production plays an important role in global warming, increased environmental damages and a significant increase in $\mathrm{CO}_{2}$ emission $[16,17]$ and increased generation of thermal energies. One of the primary solutions to the design and production of building materials is to use economically-feasible industrial byproducts and primary resources with the same properties of sustainable materials. Such materials can be used as adhesives for the building materials [18-21]. There has been a great interest in the use of pozzolanic materials as cement substitutes due to the ever-increasing consumption of cement in the construction industry. This in turn led to increased production of cement and turned it one of the largest pollutant industries. Having cement properties, pozzolanic materials reduce costs, enhance the resistance to alkaline and acidic effects of aggregates and lowers concrete cracking. Pozzolans are one of the materials that can be used as an alternative to cement.

According to ASTM-C618-94 [22] and National Building Regulations of Iran (Issue-14), pozzolan is a material containing silica or aluminum silicate without or with negligible adhesion, which is mixed with other adhesives such as cement. In aqueous media, calcium hydroxide $\left(\mathrm{CaCO}_{3}\right)$ available in the cement react to produce compounds with cement properties (hydration products). Pozzolanic materials are supplementary cementing materials (SCMs) and can be utilized as substitutes for a portion of cement [23, 24]. Multiple types of naturally occurred pozzolans such as bentonite and kaolin with cementing properties can be used as a portion of the cement. Bentonite and kaolin are amongst the naturally occurred pozzolanic materials utilized in concrete production. These materials can under particular conditions improve the compressive strength by decreasing the cement volume [25].

According to studies on bentonite carried out in Pakistan, using the material can help improve the compressive strength. According to the results, the early-age compressive strength of the concrete with added bentonite does not display much improvement, but it becomes considerably higher than the control concrete specimen at higher ages. The present study uses coarse and fine-aggregate rock materials. Moreover, the water-to-cement ratio was adjusted at 0.55 , the cement content at $340 \mathrm{~kg} / \mathrm{m}^{3}$, and the maximum bentonite replacement ratio $21 \%$. Moreover, other parameters besides the compressive strength were also tested; these included water absorption and the effects of bentonite on the concrete's resistance to acid corrosion. According to the results, the specimens with added bentonite had a better performance against acid corrosion. As regards using bentonite to replace cement, it was also shown that increasing the bentonite content undermines the performance of the concrete, drastically reducing its compressive strength and tensile strength [15, 26].

The addition of bentonite into concrete considerably enhances the durability of the concrete and prevents it from cracking after drying. The presence of various minerals in pozzolanic materials significantly influences the performance, strength and durability of the concrete [27].

Some studies have been conducted on bentonite-containing concrete to examine the mechanical behavior and durability of concrete made of recycled aggregates with low-calcium bentonite. The use of recycled rock materials has received recently great attention due to its environmental benefits. Low-calcium bentonite is a naturally occurred pozzolan utilized as a cement substitute. The bentonite mixed with concrete containing recycled materials can improve the durability and strength of the concrete [28]. The hydration process in a mixture of Portland cement containing MK and sodium bentonite has been investigated to analyze the effect of pozzolanic materials. According to the results, the mixture of sodium bentonite and metakaolin increased the hydration of cement in terms of strength improvement, portlandite consumption and calcium-silicate-hydrate ( $\mathrm{C}-\mathrm{S}-\mathrm{H})$ phase. Decomposition of MK is also accelerated in the presence of bentonite [29].

The factors affecting the strength of concrete when using meta-kaolin are the effect of fillers, acceleration rate 
of hydration reaction (OPC), and pozzolanic reaction $\mathrm{MK}$ and $\mathrm{CH}[30,31]$. From the effects of using meta-kaolin [32, 33] in mortar and concrete production, it can be noted that meta-kaolin is an effective pozzolan for replacing part of the cement in mortar and concrete [23].

Using pozzolanic materials such as metakaolin and silica gel (silica fume) in the self-compacting concrete was found to improve the compressive and tensile strength of the concrete [34]. Also, the use of carbonate kaolinite clays as cement additives can have a positive impact on the mechanical properties and mortar durability $[35,36]$. The use of epoxy resin [37] can influence the mechanical parameters and the properties of clay soils, including modulus of elasticity, stiffness, and tensile behavior, but cannot increase the strength and flexibility properties of clay soils. The type of clay mineral used in conjunction with epoxy resin is essential. Finally, it can be stated that the use of epoxy resin together with bentonite and kaolin clay minerals can increase the strength by a factor of 2 compared to when no epoxy resin is used.

One of the requirements that have been considered in the last century is the technology for recycling the wastes from various industries $[3,6,38]$, For this reason, most materials and wastes can be effective in the production of low-strength materials. The low-strength materials are also used as a replacement for sand and gravel [39]. The hydration process and the mechanical properties of the sand using the different combinations of meta-kaolin replacement levels significantly increase the heat evolution rate [40]. The factors contributing to the durability of concrete include the use of cement-like materials such as fly ash, silicon, slag, and in recent years, meta-kaolin [24, 41]. The presence of different minerals in various clay soils has a significant effect on the performance, strength, and durability [42].

Any material other than concrete and steel is a masonry material used in masonry structures. Structures made from these materials are called masonry constructions. In addition to the advantages of unreinforced masonry (URM) and reinforced masonry (RM) structures, the Confined masonry (CM) structures do not suffer from the complexities of reinforced concrete (RC) structures. The URM structures have less lateral strength than the CM structures due to postcracking strength decline. The masonry materials are suitable construction technology without requiring state-ofthe-art equipment [43]. Lignin is a by-product of paper and timber industry, and it has not been fully utilized in both developed and developing countries. Improper disposal or storage of lignin is not only a waste of natural resources, but also posing significant risk to public health and the environment. Sustainable reuse options for lignin in civil engineering infrastructures, such as road embankments and dam foundations, have been recently evaluated by laboratory testing $[3,44]$.

The extraction of raw materials, curing processes and material transportation for implementation of a project have massive impacts upon the environment. It is possible to minimize environmental damage using substitute materials for cement. The application of cement substitutes can also realize the objectives of sustainable development and sustainability. This study aims at examining the effect of naturally occurred pozzolans (e.g. bentonite and kaolin) as partial and total substitutes of cement to reduce cement consumption and improve concrete performance. Other goals of the present study included producing concrete with the minimum compressive strength required for one to two-story structures, which was realized using natural pozzolans as partial substitutes for cement that reduced cement consumption while ensuring the minimum environmental impact. This study aimed to investigate the properties of the employed materials, specifications of the fabricated specimens, their fabrication method, and the associated standards. The following section discusses the effect of using pozzolanic materials and presents and compares the results of compressive and tensile tests. The last section addresses and assesses the environmental effects of pozzolanic materials.

\section{Experimental program}

\subsection{Materials and methods}

Various materials were investigated and studied, including Bentonite, Kaolin, Montmorillonite, red clay soil, and resin. Among the consumed Bentonite properties one could refer to its good shear strength, impermeability, and compressibility. Also Kaolin is a material with different types and depending on the constituent substances, and their percentages exhibit a variety of properties.

The compressive strength test was performed on 7-day and 28-day $100 \times 100 \mathrm{~mm}$ cubic specimens according to BS-EN-12390 [45]. The tensile strength test was performed on 7-day and 28 -day $100 \times 200 \mathrm{~mm}$ cylindrical specimens according to ASTM-C496 [46] (Fig. 1).

All stages of specimen preparation were according to the ASTM standard. Grading of the fine aggregates was done according to ASTM-C136 [47], the water content determination of aggregates was according to ASTMC566, determining the volumetric mass density of aggregates was done according to ASTM-C29, specific density and those of fine grains were performed according to ASTM-C128 [48] and finally the slump test was performed according to ASTM-C143 [49] standard. 


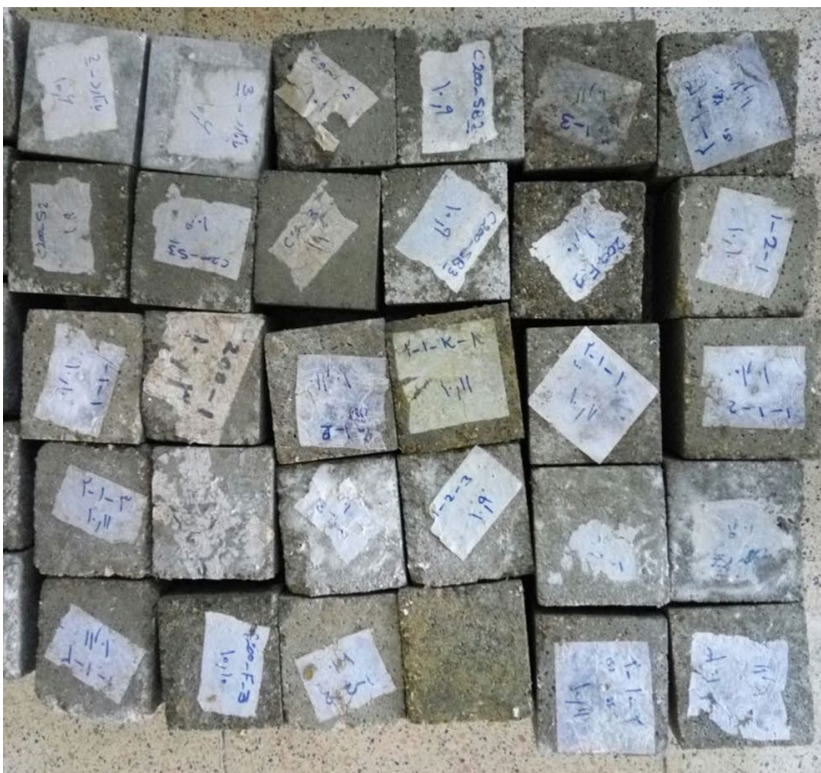

(a) Cubic specimens

Fig. 1 Specimens

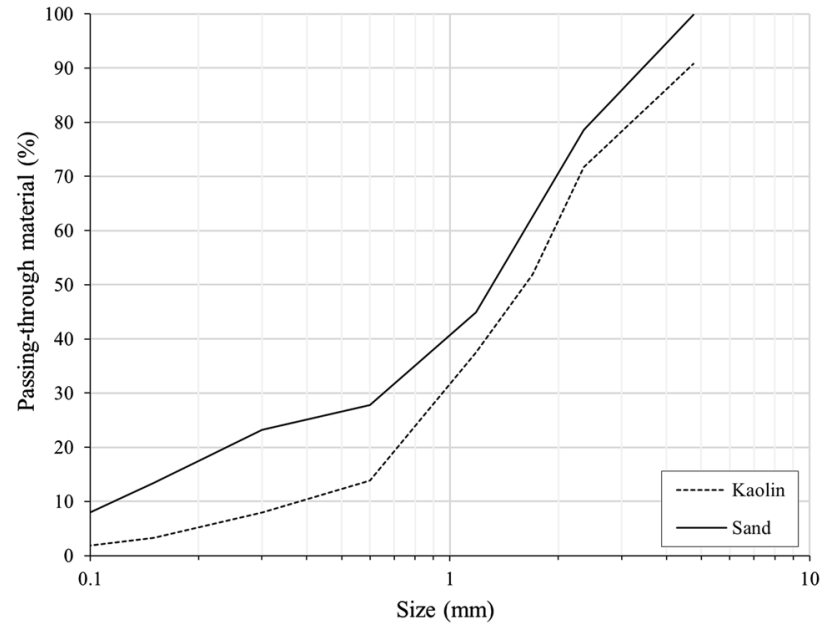

Fig. 2 Average grading curves of aggregates and kaolin

The rock materials used in this experiment were of a broken sand kind and were in the range passing sieve No. 4 $(4.75 \mathrm{~mm})$. The particle size distribution curve of the rock materials and kaolin used in the study is shown in Fig. 2.

Type II cement was used in this experiment. The Kaolin used had passed sieve No. 30 with white color, and the used

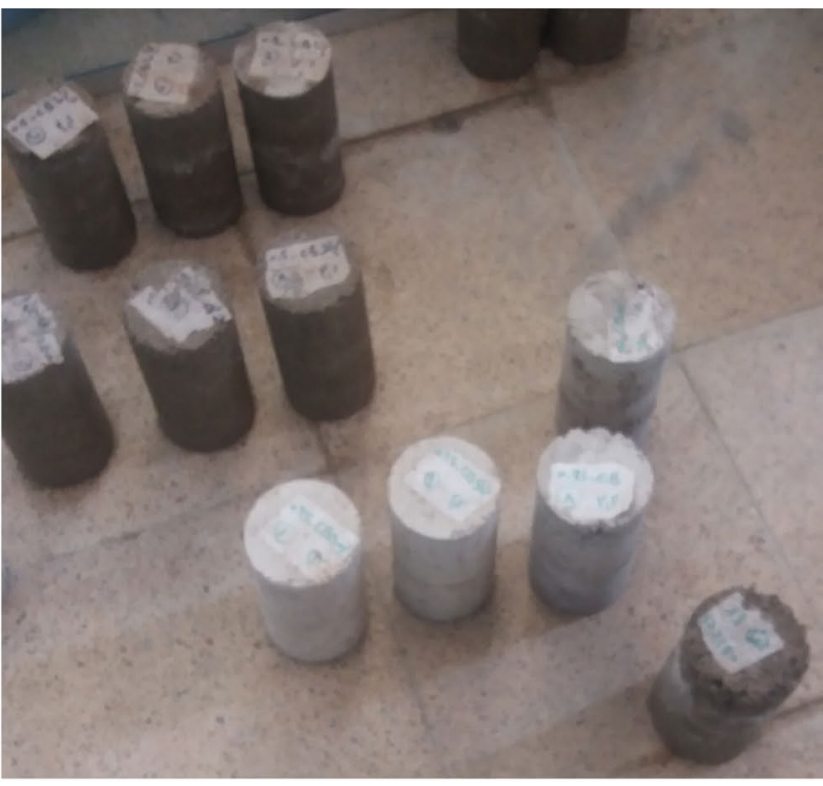

(b) Cylindrical specimens

Bentonite was also in white and with fine grains. Among other materials used in this research one could refer to the furnace slag and gum vine. The chemical analysis of the consumed Bentonite and Kaolin is shown in Table 1. The initial compound of the intended concrete is shown in Table 2. Also, the properties of the used sand and Bentonite are given in Table 3.

\subsection{Mix design and test procedures}

The goal of performing these experiments was achieving the optimal mix design in terms of the maximum compressive strength and attaining the minimum required strength. Another purpose of performing this research was the use of the materials through consideration of the sustainable development and reduction of the carbon and

Table 2 Initial composition of desired concrete

\begin{tabular}{lllll}
\hline Mix & $\begin{array}{l}\text { Fine sand } \\
\left(\mathrm{kg} / \mathrm{m}^{3}\right)\end{array}$ & $\begin{array}{l}\text { Cement } \\
\left(\mathrm{kg} / \mathrm{m}^{3}\right)\end{array}$ & $\begin{array}{l}\text { Effective water } \\
\left(\mathrm{L} / \mathrm{m}^{3}\right)\end{array}$ & Ratio w/c \\
\hline $\mathrm{CM}$ & 1607 & 433 & 260 & 0.6 \\
\hline
\end{tabular}

Table 1 Chemical analysis of pozzolans

\begin{tabular}{lllllllll}
\hline Material & $\mathrm{SiO}_{2}$ & $\mathrm{Al}_{2} \mathrm{O}_{3}$ & $\mathrm{Fe}_{2} \mathrm{O}_{3}$ & $\mathrm{MgO}$ & $\mathrm{CaO}$ & $\mathrm{Na}_{2} \mathrm{O}$ & $\mathrm{K}_{2} \mathrm{O}$ & LOI \\
\hline Bentonite & 70.75 & 9.67 & 1.8 & 0 & 1.13 & 1.47 & 0.76 & 11.24 \\
Kaolin & 66.52 & 21.96 & 0.85 & 0.37 & 0.20 & 0.83 & 0 & 4.51 \\
\hline
\end{tabular}


Table 3 Specifications of used sand and bentonite

\begin{tabular}{lll}
\hline Property & Natural sand & Bentonite \\
\hline $\begin{array}{l}\text { Particle dry density }, \rho_{p} \\
\left(\mathrm{~kg} / \mathrm{m}^{3}\right)\end{array}$ & 2410 & 2622 \\
$\begin{array}{l}24 \mathrm{~h} \text { water absorption, } \\
w_{\text {abs. } 24 h}(\%)\end{array}$ & 18.4 & 58.8 \\
\hline
\end{tabular}

greenhouse gases emission. The mix ratios were measured by weight based on the ACl 211-89 standard [50].

In this study, the specimens were investigated in three phases to achieve the best strength value (best mix design). In the first phase, about 300 different mix design plans were investigated. In the second phase, the best mix design in the previous stage was also examined, and in the final step three specimens with best mix design plans in the earlier stages were made using different curing methods and proportions and were investigated (Fig. 3). In this experiment, attempt was made to use the indigenous local and natural substances and materials of hot and arid regions.
In the initial phase, the mix design plans were obtained using the traditional and available materials in the hot and arid regions, including bentonite, Kaolin, Montmorillonite, red clay soil, and ball clay varying from $20-60 \%$. The rock materials were gypsum, limestone, rock salt, sand and thatch mortar varying from $20-60 \%$. Variation in the used water was from 15-30\%; also variation in the amount of used gum vine was from $5-20 \%$.

In the second phase, the best mix design with the highest ultimate result was also considered. In the investigations the acceptable materials were Bentonite, kaolin, furnace slag, and the additive gum vine. In this part, 25 different mix design plans were prepared using the best materials in the previous phase, which included concrete with density of $200 \mathrm{~kg} / \mathrm{m}^{3}$.

In this part, the specimens were made from those with the best results obtained in the previous stage. The mix design of the made specimens was based on the existence of Bentonite, Kaolin or lack of both of them. From the made specimens in the second phase with variable mix design plans only three optimal mix design plans have been selected and assessed. In the final phase, the

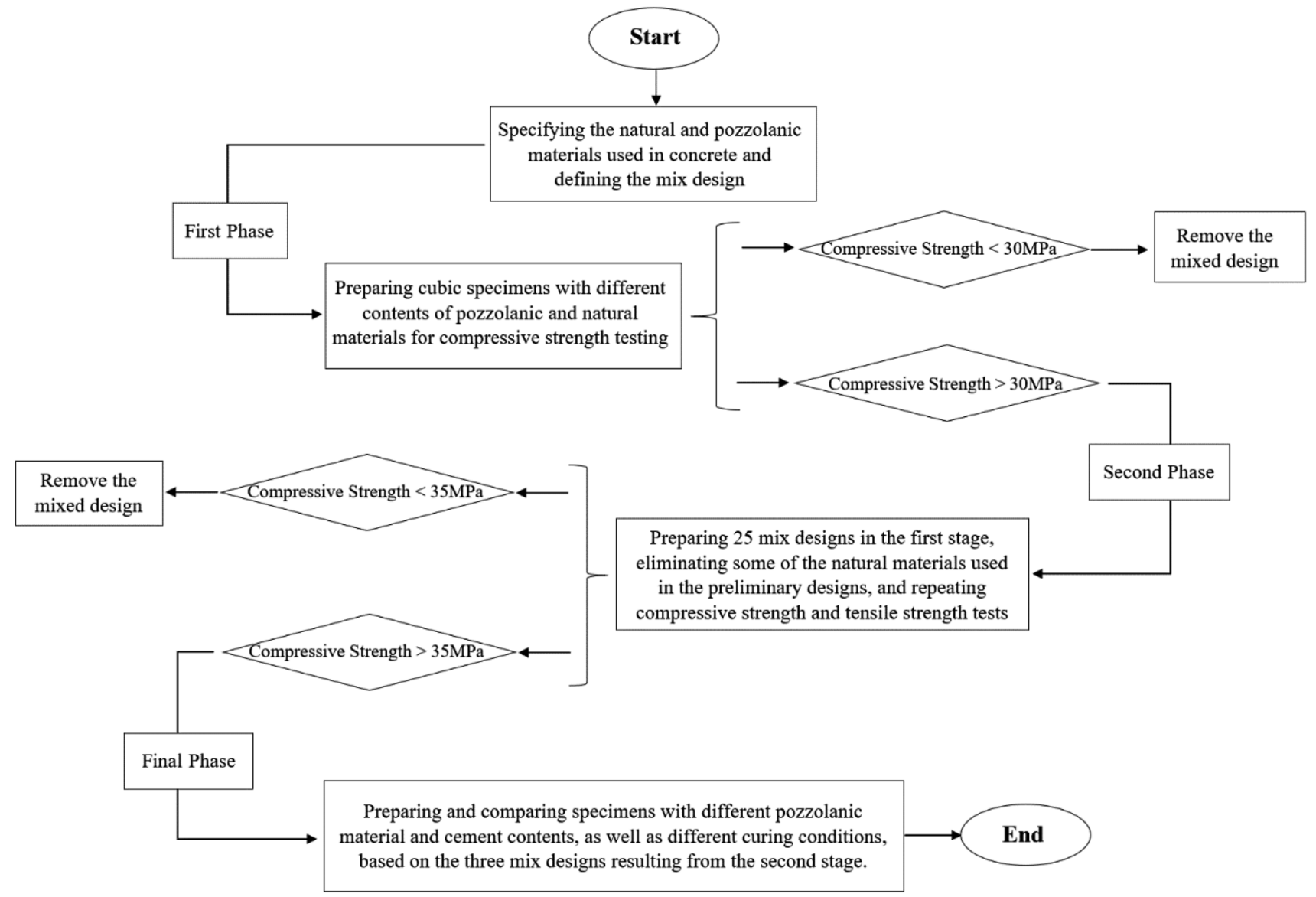

Fig. 3 Outlining the experimental procedures 
best mix design plans of the second phase, with different conditions and curing methods were made and assessed.

In Table 4, the final mix design is presented. Water to cementitious material ratio, fine aggregate content were kept constant. A vertical-shaft mixer was used to combine the materials and prepare the mixture. First, sand was mixed with $50 \%$ water present at each of the previous mix design plans before the addition of the adhesive materials, and mixing process continued for 2-3 min till the sand grains were fully wet.

For addition of Bentonite, Kaolin and other additives at different stages, the needed water for these materials, which have a high water absorption capability, was modified. In continuation, a portion of available cement in the mix design with an amount of remaining water is added to the mixture of sand and water and is mixed for $2 \mathrm{~min}$.

Finally, the pozzolanic materials and the remaining cement and water are added to the mixture, the total time needed for the mix design is about 6-7 min. The specimens were prepared and evaluated in three stages to investigate the effects of natural materials. First, all natural materials that could have been incorporated into concrete were investigated. Materials with a degrading impact on the concrete strength were set aside, and a few specimens were prepared using mix designs with optimal contents of materials that were found to offer an adequate compressive strength in the first stage.

\section{Discussion and results}

For a better presentation, the results obtained for different mix design plans are given. The SP11 mix design corresponds to those specimens which lack Bentonite; The SP21 mix design is the specimen with both Kaolin and Bentonite and the SP24 mix design is the one which lacks Kaolin.

\subsection{Pozzolanic materials}

Considering the properties of materials given in Table 3 , it could be stated that the addition of pozzolanic materials together with resin to the mixture, a better softening, and adhesion is provided. The SP11 mix design contains $2.7 \%$ Kaolin, 3.5\% furnace slag and 1.4\% resin. The SP21 specimen contains $2.6 \%$ Bentonite, $2.6 \%$ Kaolin, $1.7 \%$ furnace slag with $0.7 \%$ resin. Also in the SP24 specimen no Kaolin is utilized to investigate the effect of Kaolin. This specimen contains $2.7 \%$ Bentonite, 3.5\% furnace slag together with $1.4 \%$ resin adhesives. Regarding the obtained results we could state that in the SP21 specimen, all three pozzolanic materials are used, but the used resin amount is less than the other specimens. Accordingly the deformation and softening in the SP21 specimen are less than the other two reference specimens. The obtained deformations in these specimens were $3.21,3.12$ and $3.2 \mathrm{~mm}$, respectively. The

Table 4 Final mix proportions (final mix proportions)

\begin{tabular}{|c|c|c|c|c|c|c|c|c|}
\hline Mix & $\begin{array}{l}\text { Water } \\
\left(\mathrm{kg} / \mathrm{m}^{3}\right)\end{array}$ & $\begin{array}{l}\text { Sand } \\
\left(\mathrm{kg} / \mathrm{m}^{3}\right)\end{array}$ & $\begin{array}{l}\text { Cement } \\
\left(\mathrm{kg} / \mathrm{m}^{3}\right)\end{array}$ & $\begin{array}{l}\text { Bentonite } \\
\left(\mathrm{kg} / \mathrm{m}^{3}\right)\end{array}$ & $\begin{array}{l}\text { Kaolin } \\
\left(\mathrm{kg} / \mathrm{m}^{3}\right)\end{array}$ & $\begin{array}{l}\text { Furnace } \\
\text { slag }\left(\mathrm{kg} / \mathrm{m}^{3}\right)\end{array}$ & $\begin{array}{l}\text { Gum vine- } \\
\text { resin } \\
\left(\mathrm{kg} / \mathrm{m}^{3}\right)\end{array}$ & $\begin{array}{l}\text { Slump } \\
(\mathrm{mm})\end{array}$ \\
\hline SP11 & 260 & 1607 & 400 & 0 & 12 & 15 & 6 & 75 \\
\hline SP11-C200 & 260 & 1607 & 200 & 0 & 212 & 15 & 6 & 50 \\
\hline SP11-C0 & 260 & 1607 & - & 0 & 412 & 15 & 6 & 45 \\
\hline SP11-C0-Oven & 260 & 1607 & - & 0 & 412 & 15 & 6 & 42 \\
\hline SP11-C0-shaker & 260 & 1607 & - & 0 & 412 & 15 & 6 & 42 \\
\hline SP11-C0-Oven-shaker & 260 & 1607 & - & 0 & 412 & 15 & 6 & 42 \\
\hline SP21 & 260 & 1607 & 400 & 11.25 & 11.25 & 7.5 & 3 & 80 \\
\hline SP21-C200 & 260 & 1607 & 200 & 106 & 106 & 7.5 & 3 & 53 \\
\hline SP21-C0 & 260 & 1607 & - & 216.5 & 216.5 & 7.5 & 3 & 43 \\
\hline SP21-C0-oven & 260 & 1607 & - & 216.5 & 216.5 & 7.5 & 3 & 43 \\
\hline SP21-C0-shaker & 260 & 1607 & - & 216.5 & 216.5 & 7.5 & 3 & 43 \\
\hline SP21-C0-oven-shaker & 260 & 1607 & - & 216.5 & 216.5 & 7.5 & 3 & 43 \\
\hline SP24 & 260 & 1607 & 400 & 12 & 0 & 15 & 6 & 78 \\
\hline SP24-C200 & 260 & 1607 & 200 & 212 & 0 & 15 & 6 & 58 \\
\hline SP24-C0 & 260 & 1607 & - & 412 & 0 & 15 & 6 & 45 \\
\hline SP24-C0-oven & 260 & 1607 & - & 412 & 0 & 15 & 6 & 45 \\
\hline SP24-C0-shaker & 260 & 1607 & - & 412 & 0 & 15 & 6 & 45 \\
\hline sP24-C0-oven-shaker & 260 & 1607 & - & 412 & 0 & 15 & 6 & 45 \\
\hline CM (control mix) & 260 & 1607 & 433 & 0 & 0 & 0 & 0 & 82 \\
\hline
\end{tabular}


dry density of all mix design plans in Table 4 is taken equal to $2300 \mathrm{~kg} / \mathrm{m}^{3}$ [51]. The $2300 \mathrm{~kg} / \mathrm{m}^{3}$ is the standard value corresponding to the maximum density of regular concrete. Based on the results presented in the table, the density of the specimens can be said to decrease by adding more pozzolanic materials that is, bentonite and kaolin.

\subsection{Compressive strength}

The 28-day compressive strength of specimens in the second phase is given in Table 5. Regarding the obtained results, the SP11, SP21 and SP24 specimens are considered as the selected and base specimens.

Among the base specimens, the SP21 specimen has achieved the highest 7-day and 28-day compressive strength. Regarding the ratio of 7-day to 28-day compressive strength of the specimens, we could state that in some of them the 28-day compressive strength has not much improved concerning the 7-day one. The specimens selected for the final stage exhibited better 7-day and 28-day compressive strength results with respect to the other ones. In Fig. 4, the 7-day and 28-day compressive strength of the specimens replaced with cement are

Table 5 The best compressive strength of 7 and 28 days of the second series of samples

\begin{tabular}{llll}
\hline Sample & $f_{7 \mathrm{~d}}(\mathrm{MPa})$ & $f_{28 \mathrm{~d}}(\mathrm{MPa})$ & Ratio $f_{7 \mathrm{~d}} / f_{28 \mathrm{~d}}$ \\
\hline SP11 & 21.5 & 35.3 & 0.6 \\
SP21 & 22.6 & 35.8 & 0.63 \\
SP24 & 21.2 & 35.2 & 0.6 \\
\hline
\end{tabular}

also given. During the performed investigations, it was found that in the specimens with reduced percentage of cement and replaced with mineral and geo-materials and also the specimens with zero cement amount and cured in the oven, a higher deformation is observed than other specimens.

The specimens put into the shaker and cured in the oven, the highest rate of deformation is observed. In general, it could be stated that in specimens where a portion of their cement is replaced by other materials and a lower amount of cement is consumed; there is a higher deformation that is about two times that of the ordinary concrete.

The amounts of cement, water, and sand used in the examined specimens are identical. Among the specimens the SP11 and SP21 ones have exhibited the highest 28-day compressive strength. A small difference in their 7-day compressive strength is due to lack of using Bentonite in the SP11 specimen. Also in The SP24 specimen no kaolin is used, and the amounts of used furnace slag and resin in this specimen were similar to those used in the SP11 specimen. The difference between 7-day and 28-day compressive strength in the SP11, SP21 and SP24 could be explained in this way that the SP11 and SP24 have similar 7-day and 28-day compressive strength; also there is a small difference due to using or not using the pozzolanic materials. In the SP21 specimen, as stated before, due to the reduced amounts of pozzolanic and resin materials, this specimen exhibited a similar compressive strength like that in other selected specimens.

The specimens without cement that use was made of shaker during their making and curing were done in oven, the growth of strength was smaller with respect to
Fig. 4 Final compressive strength 7 and 28 days

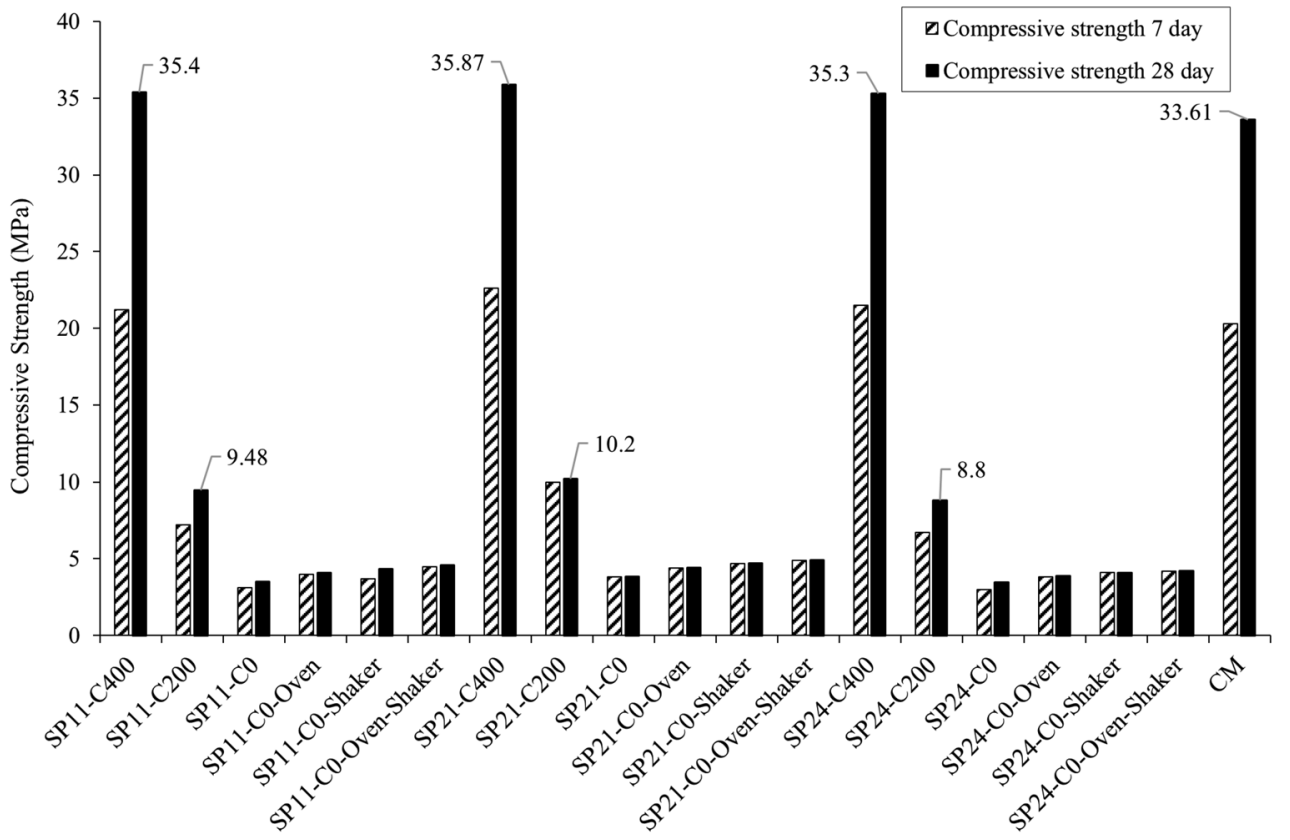

SN Applied Sciences A SPRINGER NATURE journal 


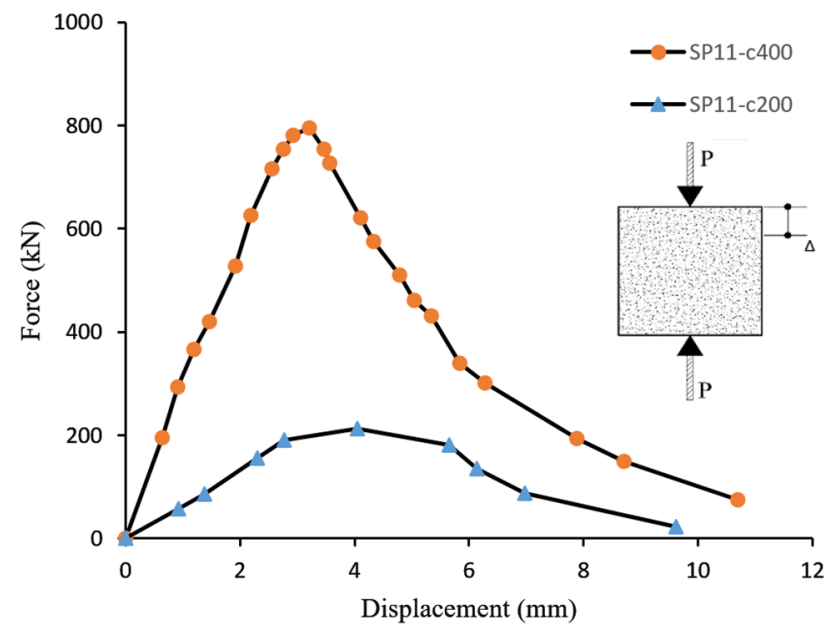

Fig. 5 Load-displacement diagram of specimen SP11

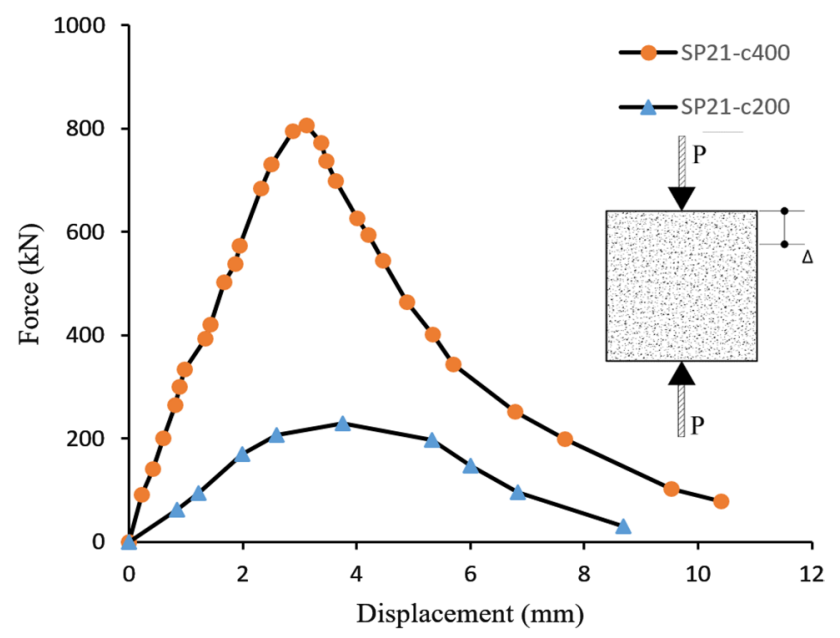

Fig. 6 Load-displacement diagram of specimen SP21

other specimens. Using the obtained information the corresponding force-displacement curve of the specimens could be drawn. In continuation, the force-displacement curves corresponding to the selected specimens, without reducing the cement and with reduced amount of cement and variation in the compressive strength, are shown in Figs. 5, 6, 7, 8 and 9 .

Considering the obtained results, the specimens which were made using a shaker and cured in the oven had higher deformation, but their compressive strength had reduced about $90 \%$ with respect to the ordinary concrete.

As seen in Figs. 8 and 9, the method of kneading and curing of the materials is effective on the deformation of the specimens. Considering the obtained results, the SP21 specimen, even under different conditions and with different curing methods, exhibited better results with respect to the other specimens.

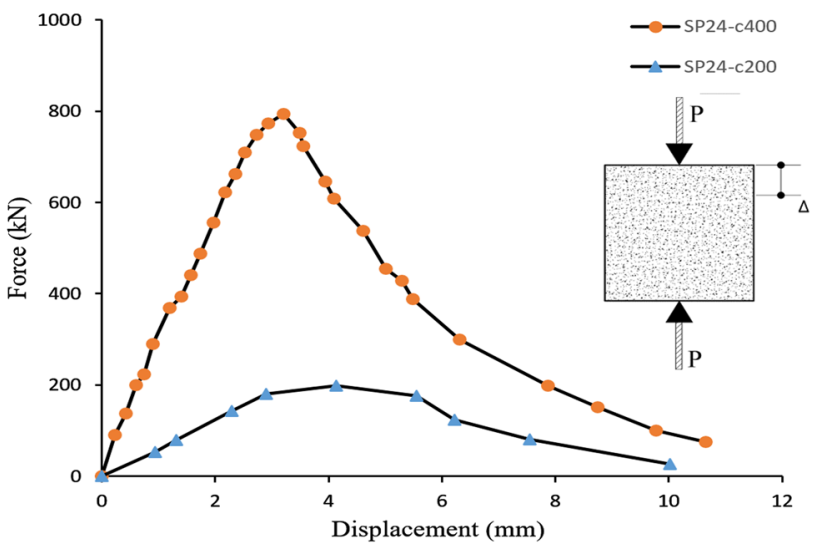

Fig. 7 Load-cement of the specimen with and without cement

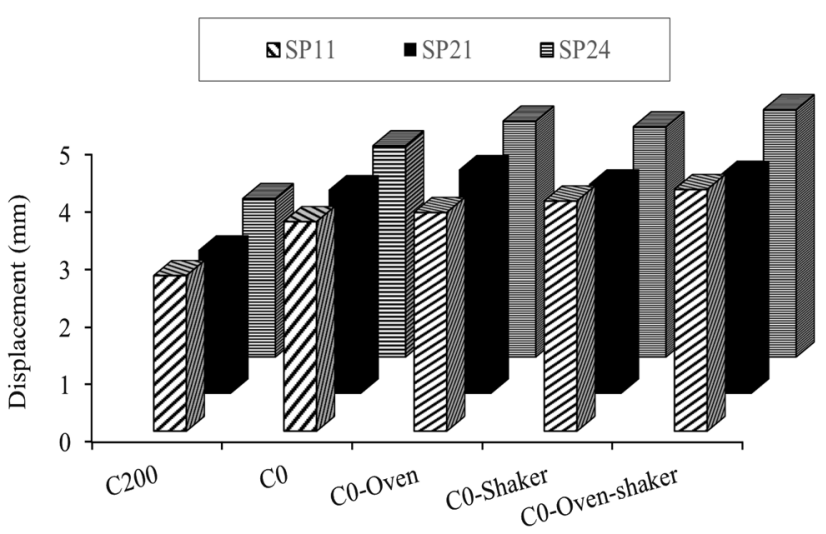

Fig. 8 Displacement of the specimen with and without cementl

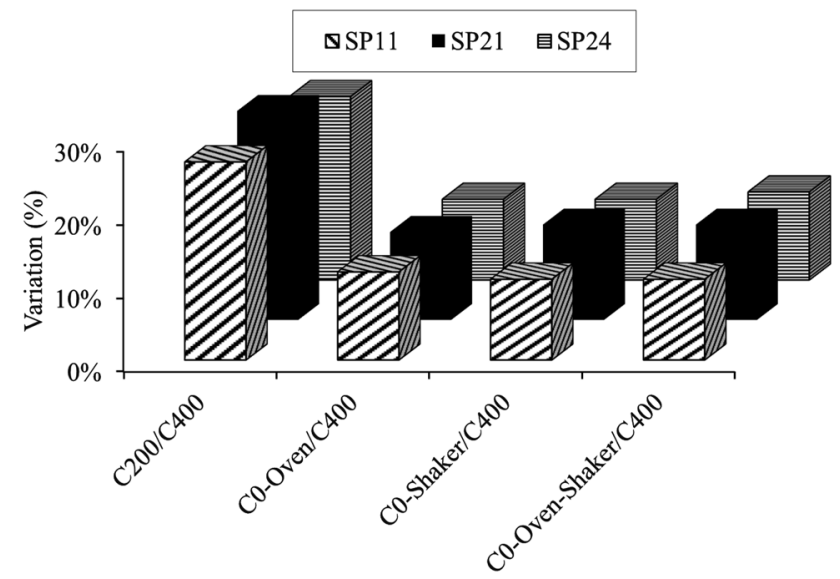

Fig. 9 Variation in the compressive strength of the specimens relative to the specimen control

In Table 6, the SP21 specimen exhibited the highest strength in different conditions. The reason is that in this specimen both Bentonite and Kaolin are used. Also in this 
Table 6 Total results

\begin{tabular}{|c|c|c|c|c|c|c|c|}
\hline \multirow[t]{2}{*}{ Specimen } & \multirow[t]{2}{*}{$\begin{array}{l}\text { Dry density } \\
\left(\mathrm{kg} / \mathrm{m}^{3}\right)\end{array}$} & \multicolumn{2}{|c|}{$\begin{array}{l}\text { Compres- } \\
\text { sive strength } \\
(\mathrm{MPa})\end{array}$} & \multicolumn{2}{|c|}{ Strain (\%) } & \multirow[t]{2}{*}{ Force 28 day (kN) } & \multirow[t]{2}{*}{$\begin{array}{l}\text { Displacement } \\
(\mathrm{mm})\end{array}$} \\
\hline & & $f_{7}^{\prime}$ & $f_{28}^{\prime}$ & $\varepsilon_{7}$ & $\varepsilon_{28}$ & & \\
\hline SP11-C400 & 2255 & 21.2 & 35.4 & 1.63 & 2.1 & 793.51 & 3.20 \\
\hline SP11-C200 & 2133 & 9.1 & 8.8 & 1.3 & 2.4 & 198.87 & 4.13 \\
\hline SP11-C0 & 2032 & 3.1 & 3.4 & 1.42 & 3.64 & 77.55 & 5.51 \\
\hline SP11-C0-oven & 2013 & 4 & 3.9 & 2.3 & 4.05 & 87.07 & 6.18 \\
\hline SP11-C0-shaker & 2015 & 3.7 & 4.1 & 1.75 & 3.8 & 92.79 & 6 \\
\hline SP11-C0-oven-shaker & 2018 & 4.5 & 4.2 & 2.1 & 4.2 & 94.78 & 6.45 \\
\hline SP21-C400 & 2225 & 22.6 & 35.87 & 1.53 & 2.08 & 806.82 & 3.12 \\
\hline SP21-C200 & 2103 & 10.1 & 10.2 & 1.24 & 2.5 & 229.5 & 3.76 \\
\hline SP21-C0 & 2052 & 3.8 & 3.8 & 1.36 & 3.55 & 86.4 & 5.32 \\
\hline SP21-C0-oven & 2020 & 4.4 & 4.4 & 2.36 & 3.9 & 98.75 & 5.83 \\
\hline SP21-C0-shaker & 2019 & 4.7 & 4.7 & 1.55 & 3.65 & 105.48 & 5.49 \\
\hline SP21-C0-oven-shaker & 2022 & 4.9 & 4.86 & 1.91 & 3.85 & 109.5 & 5.79 \\
\hline SP24-C400 & 2265 & 21.5 & 35.3 & 1.32 & 2.13 & 795.97 & 3.22 \\
\hline SP24-C200 & 2153 & 6.7 & 9.47 & 1.45 & 2.75 & 213.22 & 4.05 \\
\hline SP24-C0 & 2027 & 3 & 3.5 & 1.55 & 3.67 & 78.91 & 5.46 \\
\hline SP24-C0-oven & 2010 & 3.01 & 4.1 & 2.43 & 4.1 & 92.16 & 6.08 \\
\hline SP24-C0-shaker & 2015 & 3.2 & 4.3 & 1.94 & 4 & 97.65 & 5.71 \\
\hline SP24-C0-oven-shaker & 2020 & 3.23 & 4.6 & 2.31 & 4.3 & 103.15 & 6.33 \\
\hline CM & 2320 & 20.3 & 33.61 & 1.32 & 2.01 & 756.22 & 3.01 \\
\hline
\end{tabular}

specimen, smaller amounts of resin and furnace slag have been used with respect to other specimens. As stated, due to the characteristics of the used resin, the smaller the amount of consumed resin the better is the condition of the specimen. Use of Kaolin also causes increase in the specimen deformation. Also, use of Bentonite could have significant effect on the deformation and soften of the specimen.

As seen in Table 6, in case that the used cement density which is $400 \mathrm{~kg} / \mathrm{m}^{3}$, is reduced to half or that the specimen lacks cement, the SP11 specimen has achieved maximum compressive strength and deformation. Accordingly and regarding the obtained results, it could be stated that the SP21 specimen in any curing and making condition has exhibited the highest strength and deformation.

According to the obtained results, it could be stated that the specimens with cement and pozzolanic materials exhibit smaller deformations but higher compressive strength. But in specimens in which no cement is used and is replaced by pozzolanic materials there are higher deformations but with less compressive strength. So it could be concluded that the application of pozzolanic materials with cementitious properties for partial replacement of used cement may not have a significant role in increasing the compressive strength, but their effect in increasing deformation is considerable. Also, making specimens using the shaker and curing in the oven could affect the deformation rate. But simultaneous application of both of them could exhibit better results. Figure 10 depicts the deformation for each specimen. As is seen by changing the number of used geo-materials and conditions of their making and curing, the deformation of specimens also changes.

\subsection{Tensile strength}

The results obtained from the tensile strength testing of the 7-day and 28-day specimens are shown in Fig. 11. The cement-free specimens or those with a lower cement content have a low tensile strength similar to the compressive strength. According to the results, can be said that amongst one of the major reasons for the reduction of the tensile strength of concrete containing limited amount of cement or when cement is not used in the mix design are the physical structure of the bentonite and kaolin particles and weak bonds between their constituent-molecules. The lack of coarse aggregate materials which ultimately reduce the tensile and compressive strengths is another reason for the reduction of the strength.

According to the results, it can be said that the use of pozzolanic materials (bentonite and kaolin) together with cement with a grade of $200 \mathrm{~kg} / \mathrm{m}^{3}$ in the mixture can increase the hydration products. When the cement is not used, the compressive strength are reduced due to 


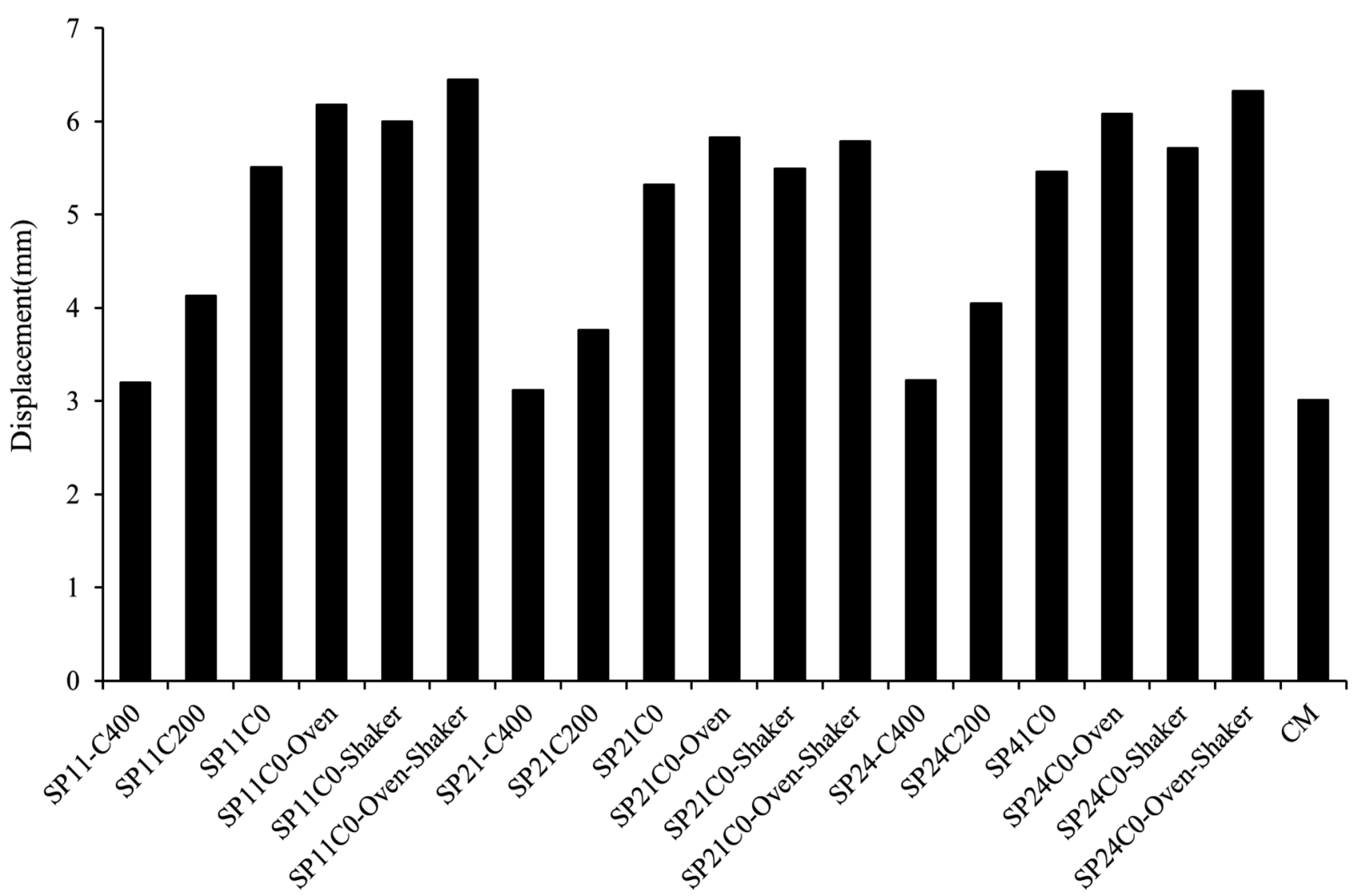

Fig. 10 Comparison of displacement

weak intermolecular bonds in the pozzolanic material and chemical properties of these materials as well as the lack of $\mathrm{CaCO}_{3}$ in the resulting mixture. Moreover, at low temperatures (about 100 to $110^{\circ} \mathrm{C}$ ) the chemical properties of the pozzolanic materials are expected to change, resulting in a decrease in the adhesive and compressive strength.

\section{Environmental assessment}

According to the studies performed on geopolymers [52-54], the geoploymeric adhesives have lower GWP with respect to the Portland Cement (PC) [55]. Based on the conducted studies, other materials such as Bentonite, Kaolin, and Metakaolin have been investigated as replacements for the cement to minimize the GWP of cementbased adhesives [56]. Other studies have been performed in terms of reducing the GWP value on Portland Cementbased mixes by increasing the GGBS [57], which shows there is possibility of reducing the GWP value in cementbased adhesives up to $65 \%$. To reach a $65 \%$ reduction, $70 \%$ of Portland cement clinker should be replaced by GGBS which is a waste material.
GWP is a measure for the emission of greenhouse gases during production of material in industry. GWP is defined based on $\mathrm{kg} \mathrm{CO}_{2}$-eq in the process of cement production. For producing 1 ton of cement, an amount about 2 tons clinker is used. For production of each ton of clinker about 0.51 tons of $\mathrm{CO}_{2}$ are emitted, which by a simple calculation it could be stated that the emitted $\mathrm{CO}_{2}$ for production of 1-ton cement is about 1.02 tons. Also for production of 1-ton sand and gravel, about 0.0302 and 0.115 tons of greenhouse gas of $\mathrm{CO}_{2}$ are emitted, respectively. In Fig. 12 the amount of generated $\mathrm{CO}_{2}$ for the used materials and mix design plans with specified cement density and different amounts of consumed aggregates is investigated and assessed. As seen in Fig. 13 by reducing the cement density to half and incorporating materials with no GWP or Low GWP value we could significantly reduce the GWP value of the mix design.

When using 1-ton cement, the GWP value is about 1.02 tons per cubic meters, but where it is reduced to 0.4 and/or 0.2 tons, the GWP value of the consumed cement reduces to 0.204 and 0.408 tons in cubic meters, respectively. Accordingly in specimens with $400 \mathrm{~kg} / \mathrm{m}^{3}$ cement, the ultimate amount of $\mathrm{CO}_{2}$ in the specimen is about 0.524 tons per cubic meters. But in specimens where the 


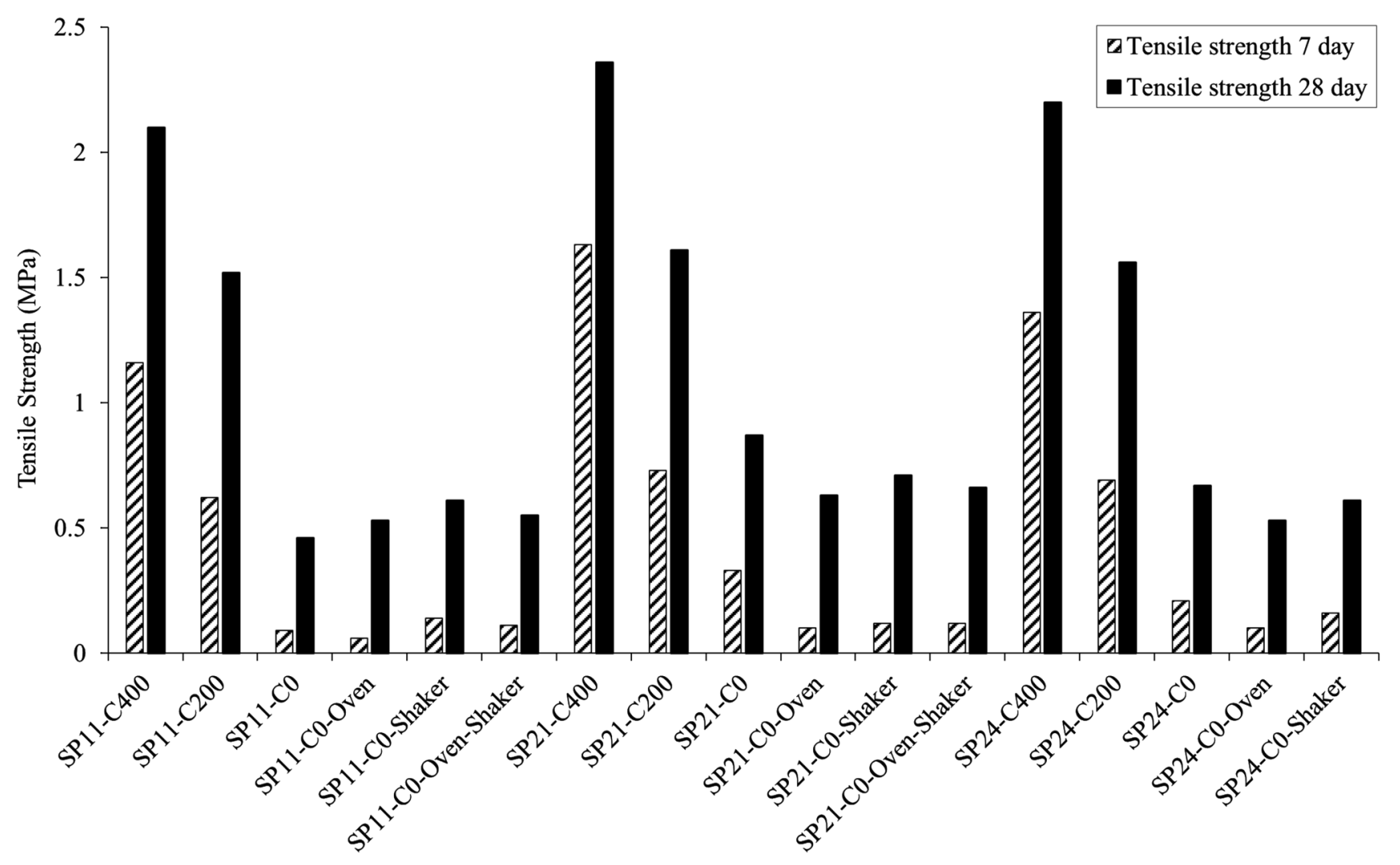

Fig. 11 Tensile strength 7 and 28 days

consumed cement is reduced to half, the ultimate $\mathrm{CO}_{2}$ in the mixture is reduced to $34.2 \%$. Also where Bentonite is used in a mixture with reduced cement to half, one could reduce the generated $\mathrm{CO}_{2}$ up to $51 \%$.

\section{Conclusion}

The present study investigates the effects of using bentonite and kaolin with furnace slag and natural resin as a partial substitute for cement in concrete. The following results were drawn from the investigations and experiments:

As natural pozzolans, bentonite and kaolin can be used as partial substitutes for cement in concrete production, thus improving its performance. Incorporating bentonite in concrete produced better results than the mix with kaolin. When used on its own to replace cement, kaolin compromises both compressive strength and tensile strength. Therefore, the kaolin replacement ratio must be kept at the minimum in concrete. The optimal bentonite replacement ratio by weight of cement in the concrete was found to be $2.7 \%$, which makes a reasonable compressive and tensile strength. The concrete is suitable for use in low-rise structures.
Reducing the cement portion and increasing bentonite and kaolin portions reduced the compressive strength and tensile strength because pozzolanic materials alone cannot compensate for cement deficiency.

Using pozzolanic materials (bentonite and kaolin) to substitute cement undermines the efficiency of the concrete. Moreover, according to the slump test results, increasing the replacement ratio by weight of cement promotes cohesion and smoothness of the mix, but undermines the efficiency of the mix. In specimens where cement was entirely replaced by pozzolanic materials, the slump was reduced considerably.

According to tensile strength results, specimens with a $400 \mathrm{~kg} / \mathrm{m}^{3}$ cement content incorporating pozzolanic materials offered a better tensile strength than the $C M$. However, by reducing the cement content or replacing it entirely, the tensile strength deteriorates significantly.

Using natural resin and furnace slag did not improve the compressive or tensile strength and even compromised the performance of the concrete. The chemical properties of natural resin call for the minimum amount of it to be used-here, $0.7 \%$.

Considering the topic of environmental assessment and GWP of the materials and mix design plans, we could state that The GWP (Global Warming Potential) of pozzolanic 


\section{GLOBAL WARMING POTENTIAL(T/M3)}

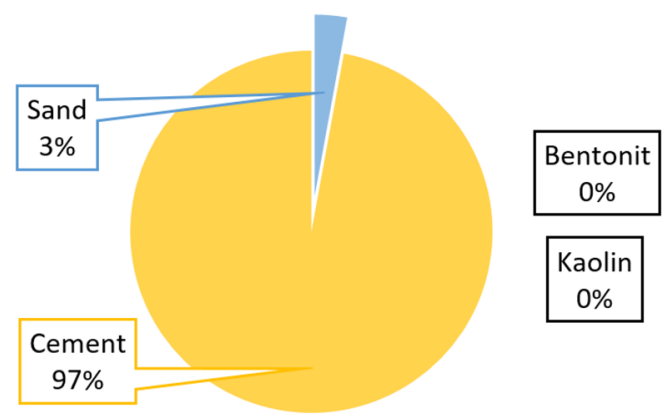

(a) GWP(Global Warming Potential)

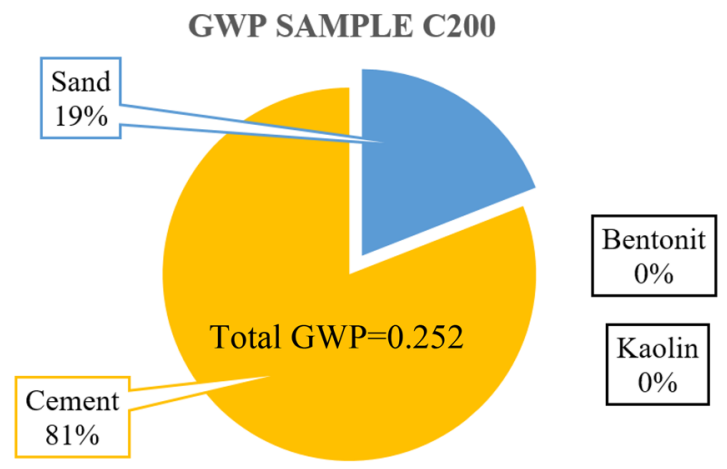

(c) GWP Sample C200

Fig. 12 GP Samples

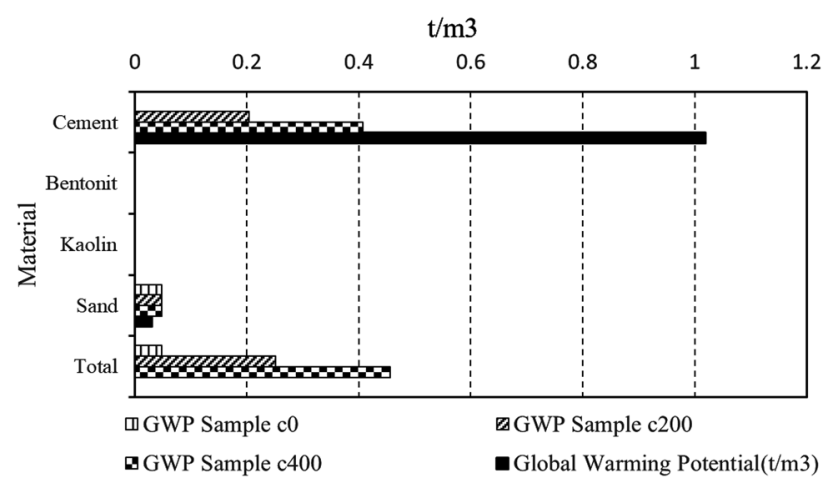

Fig. 13 Evaluation of GWP of materials and mix designs

materials is equal to zero, therefore on this basis in case the cement amount is reduced in the mix design and replaced by pozzolanic materials, we could have lower GWP values. This could be an effective way of reducing GWP of the cement contained specimens. If it is possible to add pozzolanic materials which have GWP value equal to zero, to the mixtures with low amounts of cement to compensate for reduced compressive strength, then a great evolution in the cement industry could be formed.

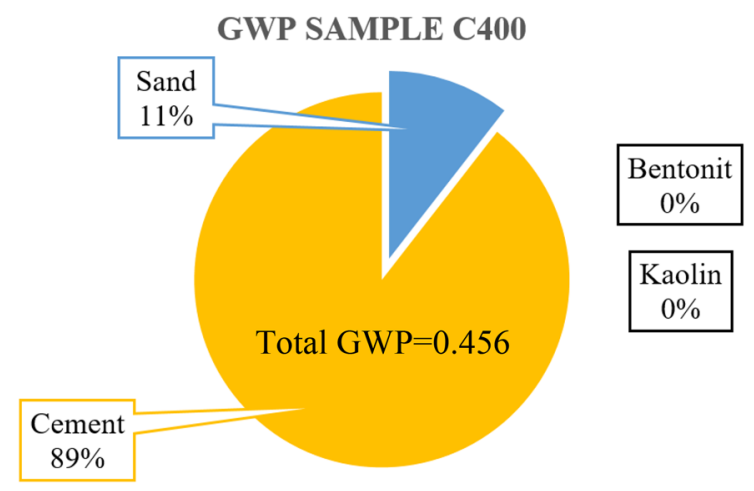

(b) GWP Sample C400

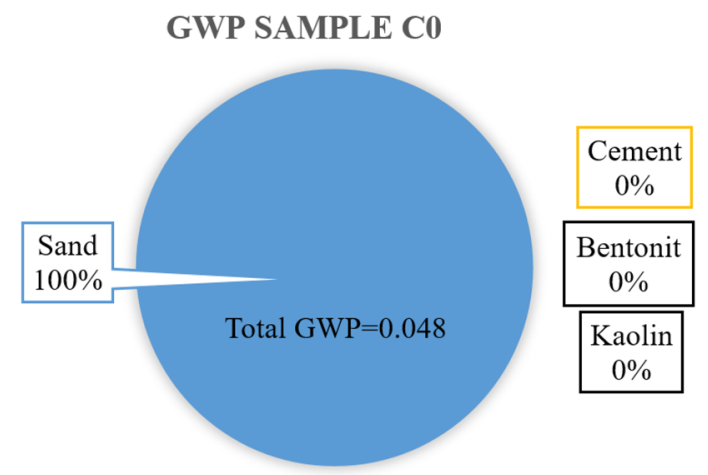

(d) GWP Sample C0

According to the main purpose of this study, the materials used for partial replacement of cement need to be compatible with sustainable development patterns and standards of admixture materials. Additionally, if used as partial replacement for cement, these materials should improve the mechanical properties of the concrete. Hence, this study only considered some of the natural pozzolans that require the least amount of energy for production.

To realize the sustainable development patterns, future studies are recommended to use zeolite along with bentonite and kaolin as partial replacement of cement for production of concrete. Coarse aggregates can also be used as a material improving the mechanical properties of concrete. The chemical structure of the product can also be analyzed to investigate the effect of these materials on the concrete stability mechanism.

\section{Compliance with ethical standards}

Conflict of interest The authors declare that there's no conflict of interests that could affect the work reported in this paper. 


\section{References}

1. Yılmaz M, Bakış A (2015) Sustainability in construction sector. Procedia-Soc Behav Sci 195:2253-2262. https://doi. org/10.1016/j.sbspro.2015.06.312

2. Osso A, Walsh T, Gottfried D, Simon NL (1996) Sustainable building technical manual. Public Technol. Inc., New York

3. Zhang T, Yang Y-L, Liu S-Y (2020) Application of biomass byproduct lignin stabilized soils as sustainable geomaterials: a review. Total Environ, Sci. https://doi.org/10.1016/j.scito tenv.2020.138830

4. Meyer C (2009) The greening of the concrete industry. Cem Concr Compos 31:601-605. https://doi.org/10.1016/j.cemco ncomp.2008.12.010

5. Lu S-M, Lu C, Tseng K-T, Chen F, Chen C-L (2013) Energy-saving potential of the industrial sector of Taiwan. Renew Sustain Energy Rev. https://doi.org/10.1016/j.rser.2013.01.021

6. Naderpour $\mathrm{H}$, Rafiean AH, Fakharian $\mathrm{P}$ (2018) Compressive strength prediction of environmentally friendly concrete using artificial neural networks. J Build Eng 16:213-219. https://doi. org/10.1016/j.jobe.2018.01.007

7. Kwan WH, Ramli M, Kam KJ, Sulieman MZ (2012) Influence of the amount of recycled coarse aggregate in concrete design and durability properties. Constr Build Mater 26:565-573. https:// doi.org/10.1016/j.conbuildmat.2011.06.059

8. Marie I, Quiasrawi H (2012) Closed-loop recycling of recycled concrete aggregates. J Clean Prod 37:243-248. https://doi. org/10.1016/j.jclepro.2012.07.020

9. Bignozzi MC (2011) Sustainable cements for green buildings construction. Procedia Eng 21:915-921

10. Ljungberg LY (2007) Materials selection and design for development of sustainable products. Mater Des 28:466-479. https:// doi.org/10.1016/j.matdes.2005.09.006

11. Cassagnabère $F$, Diederich $P$, Mouret $M$, Escadeillas $G$, Lachemi M (2013) Impact of metakaolin characteristics on the rheological properties of mortar in the fresh state. Cem Concr Compos 37:95-107. https://doi.org/10.1016/j.cemconcomp.2012.12.001

12. Gartner E (2004) Industrially interesting approaches to "lowCO2" cements. Cem Concr Res 34:1489-1498. https://doi. org/10.1016/j.cemconres.2004.01.021

13. J. Nyboer, N. Rivers, Energy Consumption Benchmark Guide, Conventional Petroleum Refining in Canada, Natural Resources Canada, Office of Energy Efficiency, Canadian Industry Progarm for Energy Conservation, 2002.

14. U. Nations (1998) Kyoto protocol to the united nations framework convention on climate change

15. Reddy GVK, Rao VR, Reddy MAK (2017) Experimental investigation of strength parameters of cement and concrete by partial replacement of cement with Indian calcium bentonite. Int J Civ Eng Technol 8:512-518

16. Heidari A, Hashempour M, Tavakoli D (2017) Using of backpropagation neural network in estimating of compressive strength of waste concrete. Soft Comput Civ Eng 1:54-64. https://doi. org/10.22115/SCCE.2017.48040

17. Onyelowe KC, Amhadi T, Ezugwu C, Ugwuanyi H, Iro U, Jideofor I, Amanamba E, Van DBUI, Salahudeen AB, Sosa F (2019) Strength of pozzolan soil blend in chemically improved lateritic soil for pavement base material purpose. Int J Low-Carbon Technol 14:410-416. https://doi.org/10.1093/ijlct/ctz035

18. Zapata-Ordúz LE, Portela G, Suárez OM (2014) Weibull statistical analysis of splitting tensile strength of concretes containing class F fly ash, micro/nano-SiO2. Ceram Int 40:7373-7388. https ://doi.org/10.1016/j.ceramint.2013.12.083

19. Nagrockiene D, Girskas G (2016) Research into the properties of concrete modified with natural zeolite addition. Constr
Build Mater 113:964-969. https://doi.org/10.1016/j.conbuildma t.2016.03.133

20. Afzal S, Shahzada K, Fahad M, Saeed S, Ashraf M (2014) Assessment of early-age autogenous shrinkage strains in concrete using bentonite clay as internal curing technique. Constr Build Mater 66:403-409. https://doi.org/10.1016/j.conbuildma t.2014.05.051

21. Aydın S, Yiğiter H, Baradan B (2007) Sulfuric acid resistance of high-volume fly ash concrete. Build Environ 42:717-721. https ://doi.org/10.1016/j.buildenv.2005.10.024

22. ASTM, Standard specification for coal fly ash and raw or calcined natural pozzolan for use in concrete/ASTM C618-08a, (2010)

23. Siddique R, Klaus J (2009) Influence of metakaolin on the properties of mortar and concrete: a review. Appl Clay Sci 43:392400. https://doi.org/10.1016/j.clay.2008.11.007

24. Mane KM, Kulkarni DK, Prakash KB (2019) Prediction of flexural strength of concrete produced by using pozzolanic materials and partly replacing NFA by MS. J Soft Comput Civ Eng 3:69-77

25. Qiyami Taklimy SM, Rezaifar O, Gholhaki M (2019) Effect of substitution of natural calcareous and clay materials with cement in low-carbon concretes. Transp Infrastruct Eng (JTIE)- (In Persian) 5:40-49. https://doi.org/10.22075/jtie.2019.19135.1431

26. Memon SA, Arsalan R, Khan S, Lo TY (2012) Utilization of Pakistani bentonite as partial replacement of cement in concrete. Constr Build Mater 30:237-242

27. Ramezanianpour AA, Pourkhorshidi AR (2004) Durability of concretes containing supplementary cementing materials under hot and aggressive environment. Spec Publ 221:633-646

28. Masood B, Elahi A, Barbhuiya S, Ali B (2020) Mechanical and durability performance of recycled aggregate concrete incorporating low calcium bentonite. Constr Build Mater 237:117760. https://doi.org/10.1016/j.conbuildmat.2019.117760

29. Wei J, Gencturk B (2019) Hydration of ternary Portland cement blends containing metakaolin and sodium bentonite. Cem Concr Res 123:105772. https://doi.org/10.1016/j.cemco nres.2019.05.017

30. Wild S, Khatib JM, Jones A (1996) Relative strength, pozzolanic activity and cement hydration in superplasticised metakaolin concrete. Cem Concr Res 26:1537-1544. https://doi. org/10.1016/0008-8846(96)00148-2

31. Batis G, Pantazopoulou P, Tsivilis S, Badogiannis E (2005) The effect of metakaolin on the corrosion behavior of cement mortars. Cem Concr Compos 27:125-130

32. Cyr M, Trinh M, Husson B, Casaux-Ginestet G (2014) Effect of cement type on metakaolin efficiency. Cem Concr Res 64:63-72. https://doi.org/10.1016/j.cemconres.2014.06.007

33. Kohout J, Koutník P, Bezucha P, Kwoczynski Z (2019) Leachability of the metakaolinite-rich materials in different alkaline solutions. Mater Today Commun 21:100669

34. Sharbatdar MK, Abbasi M, Fakharian P (2020) Improving the properties of self-compacted concrete with using combined silica fume and metakaolin. Period Polytech Civ Eng. https:// doi.org/10.3311/PPci.11463

35. Tironi A, Trezza MA, Scian AN, Irassar EF (2014) Potential use of Argentine kaolinitic clays as pozzolanic material. Appl Clay Sci 101:468-476. https://doi.org/10.1016/j.clay.2014.09.009

36. Tironi A, Cravero F, Scian AN, Irassar EF (2017) Pozzolanic activity of calcined halloysite-rich kaolinitic clays. Appl Clay Sci 147:1118. https://doi.org/10.1016/j.clay.2017.07.018

37. Hamidi S, Marandi SM (2018) Clay concrete and effect of clay minerals types on stabilized soft clay soils by epoxy resin. Appl Clay Sci 151:92-101. https://doi.org/10.1016/j.clay.2017.10.010

38. Bogas JA, de Brito J, Figueiredo JM (2015) Mechanical characterization of concrete produced with recycled lightweight expanded clay aggregate concrete. J Clean Prod 89:187-195. https://doi.org/10.1016/j.jclepro.2014.11.015 
39. Horiguchi T, Fujita R, Shimura K (2010) Applicability of controlled low-strength materials with incinerated sewage sludge ash and crushed-stone powder. J Mater Civ Eng 23:767-771

40. Janotka I, Puertas F, Palacios M, Kuliffayová M, Varga C (2010) Metakaolin sand-blended-cement pastes: rheology, hydration process and mechanical properties. Constr Build Mater 24:791802. https://doi.org/10.1016/j.conbuildmat.2009.10.028

41. Shekarchi M, Bonakdar A, Bakhshi M, Mirdamadi A, Mobasher B (2010) Transport properties in metakaolin blended concrete. Constr Build Mater 24:2217-2223. https://doi.org/10.1016/j. conbuildmat.2010.04.035

42. Nehdi ML (2014) Clay in cement-based materials: critical overview of state-of-the-art. Constr Build Mater 51:372-382. https ://doi.org/10.1016/j.conbuildmat.2013.10.059

43. Borah B, Singhal V, Kaushik HB (2019) Sustainable housing using confined masonry buildings. SN Appl Sci 1:983

44. Zhang T, Cai G, Liu S (2017) Application of lignin-based by-product stabilized silty soil in highway subgrade: a field investigation. J Clean Prod 142:4243-4257

45. BSI, Standard: testing hardened concrete. Compressive strength of test specimens/ BS EN 12390-3: 2009, (2011)

46. C. ASTM, Standard test method for splitting tensile strength of cylindrical concrete specimens, (2011).

47. C. ASTM, ASTM-C 136: Standard test method for sieve analysis of fine and coarse aggregates, (2006)

48. C. ASTM, ASTM-C128: Standard test method for specific gravity and absorption of, (2001)

49. Astm C (1996) ASTM-C143: standard test method for slump of hydraulic cement concrete, ASTM International, West Conshohocken, vol 4. PA, USA
50. ACl, Standard: concrete mix design ACl 211.1-91, (1991)

51. BSI, BS 8500-1: Concrete-complementary British standard, (2006)

52. Duxson P, Provis JL, Lukey GC, Mallicoat SW, Kriven WM, Van Deventer JSJ (2005) Understanding the relationship between geopolymer composition, microstructure and mechanical properties. Colloids Surf A Physicochem Eng Asp 269:47-58

53. Chindaprasirt $P$, Jaturapitakkul C, Sinsiri T (2005) Effect of fly ash fineness on compressive strength and pore size of blended cement paste. Cem Concr Compos 27:425-428

54. Rovnaník P (2010) Effect of curing temperature on the development of hard structure of metakaolin-based geopolymer. Constr Build Mater 24:1176-1183

55. Heath A, Paine K, McManus M (2014) Minimising the global warming potential of clay based geopolymers. J Clean Prod 78:75-83

56. Metz B, Davidson O, Bosch P, Dave R, Meyer L (2007) Climate change 2007: mitigation of climate change. Cambridge University Press, Cambridge

57. Feiz R, Ammenberg J, Baas L, Eklund M, Helgstrand A, Marshall $R$ (2015) Improving the CO2 performance of cement, part I: utilizing life-cycle assessment and key performance indicators to assess development within the cement industry. J Clean Prod 98:272-281

Publisher's Note Springer Nature remains neutral with regard to jurisdictional claims in published maps and institutional affiliations. 